\title{
Rural Community-Perceived Benefits of a Music Festival
}

\author{
Daniel Ioan Chiciudean ${ }^{1}$, Rezhen Harun ${ }^{2}$, Iulia Cristina Muresan ${ }^{1}$, Felix Horatiu Arion ${ }^{1}(\mathbb{D}$ \\ and Gabriela Ofelia Chiciudean ${ }^{1, *}$ \\ 1 Department of Economic Sciences, University of Agricultural Sciences and Veterinary Medicine of \\ Cluj-Napoca, 400372 Cluj-Napoca, Romania; daniel.chiciudean@usamvcluj.ro (D.I.C.); \\ iulia.muresan@usamvcluj.ro (I.C.M.); felixarion@usamvcluj.ro (F.H.A.) \\ 2 Department of Agribusiness and Rural Development, College of Agricultural Sciences Engineering, \\ University of Sulaimani, Kurdistan Regional Government-Iraq, Sulaimani-IRAQ 334, Iraq; \\ rezhen.rashid@univsul.edu.iq \\ * Correspondence: gabriela.chiciudean@usamvcluj.ro
}

Citation: Chiciudean, D.I.; Harun, R.; Muresan, I.C.; Arion, F.H.;

Chiciudean, G.O. Rural CommunityPerceived Benefits of a Music Festival. Societies 2021, 11, 59. https:// doi.org/10.3390/soc11020059

Academic Editor: Gregor Wolbring

Received: 5 May 2021

Accepted: 8 June 2021

Published: 11 June 2021

Publisher's Note: MDPI stays neutral with regard to jurisdictional claims in published maps and institutional affiliations.

\begin{abstract}
There is a general consensus that tourism activity must have the support of a local community in order to build sustainable tourism development. Among the competitive Romanian tourism products, festival tourism should be mentioned, even though it is relatively new. Therefore, given the traditional communities from rural areas which are confronted with an international flux of tourists, it is vital to analyze the perception of and support for festivals. The presumption is that if there are benefits for the locals, support increases. In order to achieve the objective of the study, research has been conducted among the local rural community of Bontida, which is the location of an international annual music festival. The instrument used was a questionnaire which had four parts that aimed to measure the cultural benefits and costs of the festival and the sense of well-being of the community, given the fact that previous studies focused mainly on the economic and environmental impacts, but not so much on the socio-cultural dimensions. Descriptive statistics were used to analyze the data. The results indicated that the benefits are greater than the perceived costs, a fact which is encouraging from the perspective of developing a sustainable tourism strategy, both by the local authorities and private stakeholders.
\end{abstract}

Keywords: rural community; music festival; festival tourism; community well-being; socio-cultural benefits; residents' support

\section{Introduction}

Over the last decade, increased attention has been paid to evaluating the impact of tourism on the perceptions and attitudes of local communities because of the direct relation of these communities' support for tourism development [1-8], which could also be a major factor in building a destination brand [9] and implicitly contributing to the development of local tourism [10-12]. Most of the previous research focused particularly on the economic impact of tourism [13-15], and the conclusions pointed out that residents see tourism as a developing economic tool that reduces unemployment, brings in new businesses and creates new investment opportunities by generating revenue for local communities and governments [16-18]. There is therefore a positive relationship in terms of attitudes and benefits towards tourism [19-23]. Besides the fact that tourism has a significant influence on the economy, it determines and influences the socio-cultural life of local communities in terms of lifestyle, cultural values, exchanging ideas between individuals by direct interaction [24], level of education and civilization [25-27]. Another important issue which tourism enables within host communities refers to increased quality of life. A study conducted in Kazakhstan illustrates how a tourism infrastructure project could have a positive effect on developing tourism opportunities among the host community, which played an enormous role in its support [28]. Due to the fact that many communities have different cultures and traditions, the development of tourism has different effects on them, 
especially when it comes to international festival tourism, which brings together many nationalities from all over the world. Therefore, the impact of such events is important for analysis within traditional communities such as the Romanian villages, given their ability to preserve traditional culture and ethno-cultural heritage [29,30]; however, it is also important to revitalize old traditions and invent new reasons to celebrate, especially in rural areas [31]. Tourism is generally one of the main industries which has many employees and strongly contributes to economic growth [32] but, in Romania, this sector contributes only a small percentage to gross domestic product compared to other countries from the European Union (only $2.7 \%$ in 2019, while Croatia, for example, held 20\%) [33], even though Romania's tourism potential is very high [34,35]. Among the competitive tourism products that Romania could offer on the international tourism market, festival tourism could be a viable option; however, in order to achieve this goal, it is necessary to identify how international festivals are perceived by host communities [36]. One such festival has been taking place each year in Bontida commune (Cluj County) for seven years. The 2019 edition of the international electronic music festival gathered 231,000 people from all over the world; there were 15,000 campers and more than 300 artists. Given the huge impact that the COVID-19 crisis has had on the travel and leisure industries-temporarily stopping the festival in 2020 and also in 2021 - it is important to analyze the community's perception from the perspective of finding a means to recover, with aid from the government and from local stakeholders [37], as well as to create a future competitive destination brand. This is because the "cash injection" following these events is important for local rural development, but it is not enough for a successful festival. Rather, community involvement is the most important element [38]. Therefore, in the Literature Review section, the impact of tourism festivals on local rural communities was analyzed based on previous research, as was the influence of socio-demographic characteristics on the perceived impact of tourism festival on residents. The Material and Methods section comprises data referring to the area of the research, but also describing the method used to gather and analyze data. The results of the research are presented in the fourth section, and the discussions are presented in light of previous research. In the Conclusions section, the main findings are structured, along with the managerial implications and the main contribution to the field.

\section{Literature Review}

\subsection{Impact of Tourism Festivals on the Local Rural Communities}

Much research has pointed out how festivals have a huge social impact on the communities in which they are set, and which can be manifested either by positive (community development, community pride) [39] or by the negative social changes (overcrowding, inadmissible noise level, crime rate and vandalism) [39,40]. Festivals and events help to better display a community [41-43], promoting its attractions and attracting more visitors and participants, but also investors and sponsors, thus generating a strong devotion and commitment of residents to the community, as well as a revitalization of the commune. The events that take place in a community do not only have positive and negative effects on the tenants, as they also offer visitors a multitude of benefits and opportunities, as well as the satisfaction of different needs. Therefore, the organization of events and festivals represents, both for residents and for visitors, many opportunities which can be educational, cultural and also economic, manifesting themselves in a positive and beneficial way $[44,45]$. On the other hand, the organization of these events and festivals improves people's health through relationships and social interactions [46], and facilitates the exchange of ideas between communities and how they communicate, with the end result reducing depression and loneliness and allowing individuals to acquire a sense of belonging to a community and a place [47,48], but also creating the premises for better participation of both rural residents and stakeholders in order to build a viable and sustainable local development strategies [48]. Studies which approach and analyze community perceptions of sustainable tourism development [3,49-55] usually consider three dimensions (economic, environmental and socio-cultural) as a whole, and rarely focus on a specific one, such 
as the socio-cultural dimension, as a key element for gaining community support. Yolal et al. [26] brought to attention the relationship between community socio-cultural benefits and subjective well-being by outlining the importance of tourism activities. A similar study was conducted in Pakistan using a model based on three exogenous constructs (religious commitment, belief and practice) and one latent endogenous construct (socio-cultural impact). Results indicated that a high level of religiosity is related to a stronger support for sustainable tourism development [56], measured by growth in income and employment as main indicators [57].

\subsection{Influence of the Socio-Demographic Characteristics on the Perceived Festival Tourism Benefits}

Socio-demographic characteristics seem to have a major influence on the way tourism is generally perceived by a host community [6]. Gender differences exist when it comes to analyzing the perceived socio-cultural impact of tourism development according to some researches [58,59], who state that women tend to perceive it more positively than men. Other studies highlighted the fact that women are more preoccupied by environmental impact than men [60] because of their need for a safer life. Previous research has stated that respondents' age influences the perception of tourism development [3,61-65], with stronger support being observed in older people. Education is another predictor for residents support for tourism development; scholars generally observed that, the more educated residents are, the more positive they perceive tourism activity [66-69]. With regard to the relation between income level and the support for tourism, Long and Kayat [70] concluded that people with higher levels of income tend to perceive tourism impacts more positively, while residents with lower levels of income tend to perceived it more negatively.

The main aim of this research is analyze how a music festival can affect the life of a rural community. How much does such an event affect its host community? Can a music festival improve the socio-cultural development and wellbeing of rural residents? Do socio-demographic characteristics affect the perception of cultural impacts?

\section{Materials and Methods}

The main objective of the research was to determine the impact that the development of event tourism has on a local community from Bontida, Cluj County, where, each year in July, starting from 2013, a famous international music festival has taken place. The COVID-19 crisis temporarily stopped the festival in 2020, and maybe will do so in 2021. Bontida commune is located $30 \mathrm{~km}$ next to Cluj-Napoca municipality, which is the center of the Romania North-West region of development. The commune has a population of 5098 citizens [71].

\subsection{Reasearch Methdology}

To achieve the aim of the paper, firstly, an analysis of the secondary data was conducted to identify the factors that influence local communities' perceptions and attitudes towards tourism development. At this stage of the research, a deep analysis of research presenting the influence of festival tourism on the host community was conducted. Thus, 20 items referring to the cultural and well-being dimensions were identified, following previous research [26]. Subsequently a survey was conducted in the Bontida commune during August-December 2019 using face-to-face interviews as a contact method.

\subsection{Questionnaire Design}

The questionnaire had four parts, of which the first part contained items for measuring the cultural benefits and costs of the festival. In the second part, the objective was to determine the sense of well-being in the community based on previous studies [26] and, in the third part, respondents were asked about their economic activity related to the festival. The forth part of the questionnaire included socio-demographical questions. The items from the first two sections were constructed using the five-point Likert scale, similar to the research of Yolal et al. [26], where 1 means "total disagreement" and 5 means "total 
agreement" for each of the 20 items referring to the cultural and well-being dimensions. The 20 items were divided into 5 main dimensions: community benefits ( 5 items); cultural and educational benefits (4 items); quality of life concerns (4 items); community resource concerns (4 items); subjective well-being of respondents (3 items).

\subsection{Sample Size}

The empirical study was based on a convenience sample of 136 responses. The interviewer collected the data in the main points of the commune where the inhabitants gather frequently (Local Church, Community Center). Before starting the interview, the aim of the survey was explained to each respondent, and consent to participate in the study was obtained.

The sample is quite balanced regarding the respondents' genders following the structure of the population from the commune; according to official data, 2388 were males and 2438 were females [72]. The structure of the sample by age indicated a large percent $(47.8 \%)$ of young respondents, a fact explained by the commune's proximity to Cluj-Napoca, but seniors were also well represented. A total $13.2 \%$ were aged between $50-59$ years and $8.8 \%$ were 60 years or older. It was also noted that younger persons were more open to participating in surveys and interviews, without receiving any reward, compared to older people [73].

The education level indicated that the sample is also educated; almost half of the respondents finished high-school (47.8\%) and only $12.5 \%$ were limited to primary studies. The occupations of the respondents illustrate that $62.5 \%$ of them are employees, a fact which can be explained by the strong presence of many international companies in Bontida commune and its proximity to Cluj-Napoca Municipality. The category of entrepreneurs is not so large. Only $5.9 \%$ of the respondents declared that they own a business, while $10.3 \%$ are retirees. Given the level of medium income in Romania, which is almost EUR 670, the analyzed data indicated that almost $70 \%$ of the inhabitants earn less (Table 1).

Table 1. Socio-demographic profile of respondents.

\begin{tabular}{|c|c|c|c|}
\hline Characteristics & Variables & Number of Responses $n=136$ & Percent of Responses (\%) \\
\hline \multirow{2}{*}{ Gender } & Male & 66 & 48.5 \\
\hline & Female & 70 & 51.5 \\
\hline \multirow[t]{5}{*}{ Age (years) } & $18-29$ & 65 & 47.8 \\
\hline & $30-39$ & 26 & 19.1 \\
\hline & $40-49$ & 15 & 11.0 \\
\hline & $50-59$ & 18 & 13.2 \\
\hline & +60 & 12 & 8.8 \\
\hline \multirow[t]{4}{*}{ Education level } & Primary school & 17 & 12.5 \\
\hline & High school & 65 & 47.8 \\
\hline & Faculty & 44 & 32.4 \\
\hline & Post-graduate & 10 & 7.4 \\
\hline \multirow[t]{5}{*}{ Occupation } & Student & 25 & 18.4 \\
\hline & Employee & 85 & 62.5 \\
\hline & Entrepreneur & 8 & 5.9 \\
\hline & Household & 4 & 2.9 \\
\hline & Retiree & 14 & 10.3 \\
\hline \multirow[t]{6}{*}{ Monthly income per person } & EUR $<200$ & 14 & 10.3 \\
\hline & EUR 200-320 & 25 & 18.4 \\
\hline & EUR 321-440 & 31 & 22.8 \\
\hline & EUR 441-560 & 24 & 17.6 \\
\hline & EUR 561-680 & 11 & 8.1 \\
\hline & EUR > 680 & 31 & 22.8 \\
\hline
\end{tabular}




\subsection{Data Analysis}

Data were analyzed using the SPSS 19.0 software package (SPSS Inc., Chicago, IL, USA). The respondents' profiles were determined using descriptive statistics. The same method was applied for measuring the means and standard deviations of each item used in the questionnaire. Internal consistency of the 20 items used and the reliability of the data was determined using Cronbach's alpha $(\alpha=0.827)$. Furthermore, the reliability test was conducted for all 5 dimensions: community benefits $(\alpha=0.842)$; cultural and educational benefits $(\alpha=0.887)$; quality of life concerns $(\alpha=0.811)$; community resource concerns $(\alpha=0.761)$; subjective well-being of respondents $(\alpha=0.902)$. The values exceed the recommend significant level of 0.6 [74], indicating a good consistency of the data. During the next step of the data analysis, the Shapiro-Wilk test was performed to test the normality of the statements $(p<0.05)$; thus, the Mann-Whitney U test was chosen to compare the two groups (female and male) and the Kruskal-Wallis test was used to analyzed whether there were any significant differences among the other groups (classified based on age, educational level, and monthly income). The Shapiro-Wilk test was used to test the normality of the statements $(p<0.05)$; thus, the Mann-Whitney $\mathrm{U}$ test was chosen to compare the two groups (female and male) and the Kruskal Wallis test was used to analyzed whether there were any significant differences among the other groups (classified based on age, educational level, and monthly income).

\section{Results}

\subsection{Local Residents' Attitude towards the Impact of the Festival on the Economic Development of} the Commune

Many local respondents are directly involved in offering tourism services for the tourists during the festival, and only a small percentage of $5 \%$ declared that they do not offer tourism services. Among the essential tourism services offered by the locals, it can be mentioned that accommodation is offered by $33 \%$ of the respondents, food services are offered by $6.60 \%$ of them, while $9.40 \%$ offer both food services and accommodation. The highest percentage of locals offer other types of service $(46 \%)$, such as car parking and entertainment (Figure 1).

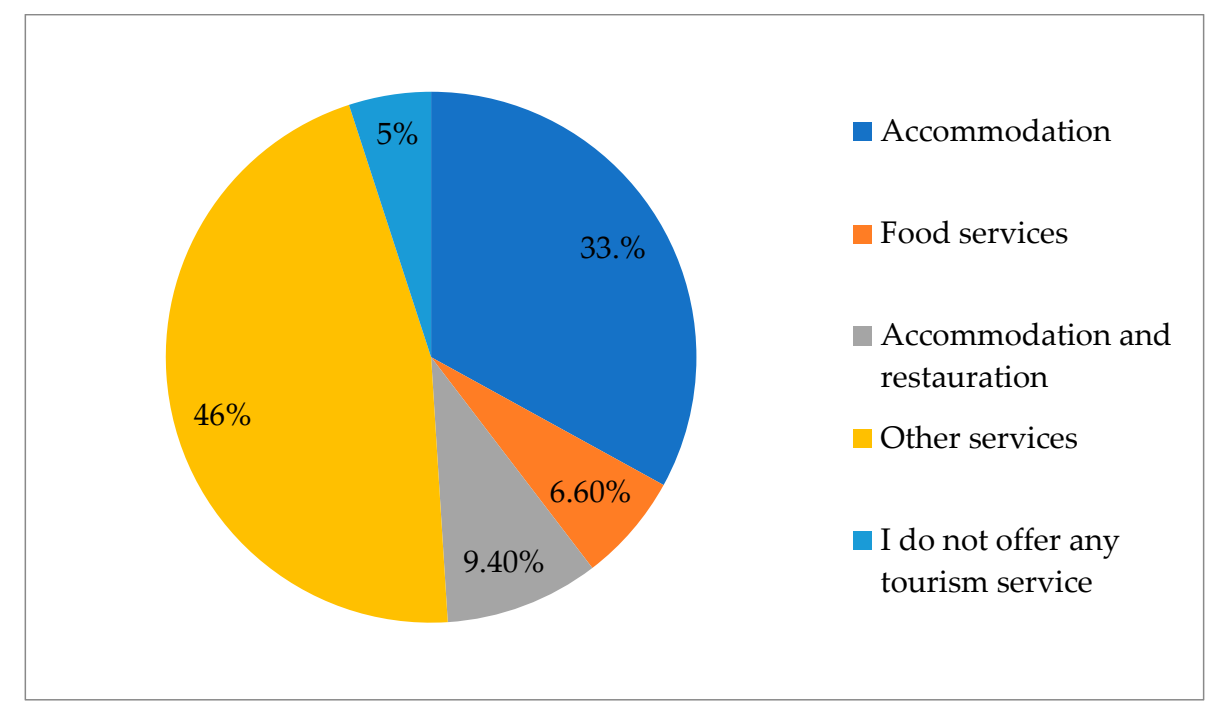

Figure 1. Type of tourism service offered by the local respondents during the festival.

Another important aspect was to determine whether locals were willing to offer tourism services in the future. It can be observed that a huge percentage of $69.7 \%$ answered positively. For $6.7 \%$, the effort to offer these services is too big and for $14.39 \%$, the gain is perceived as too small. However, for $9.2 \%$, previous damages were too important to continue in the future (Figure 2). 


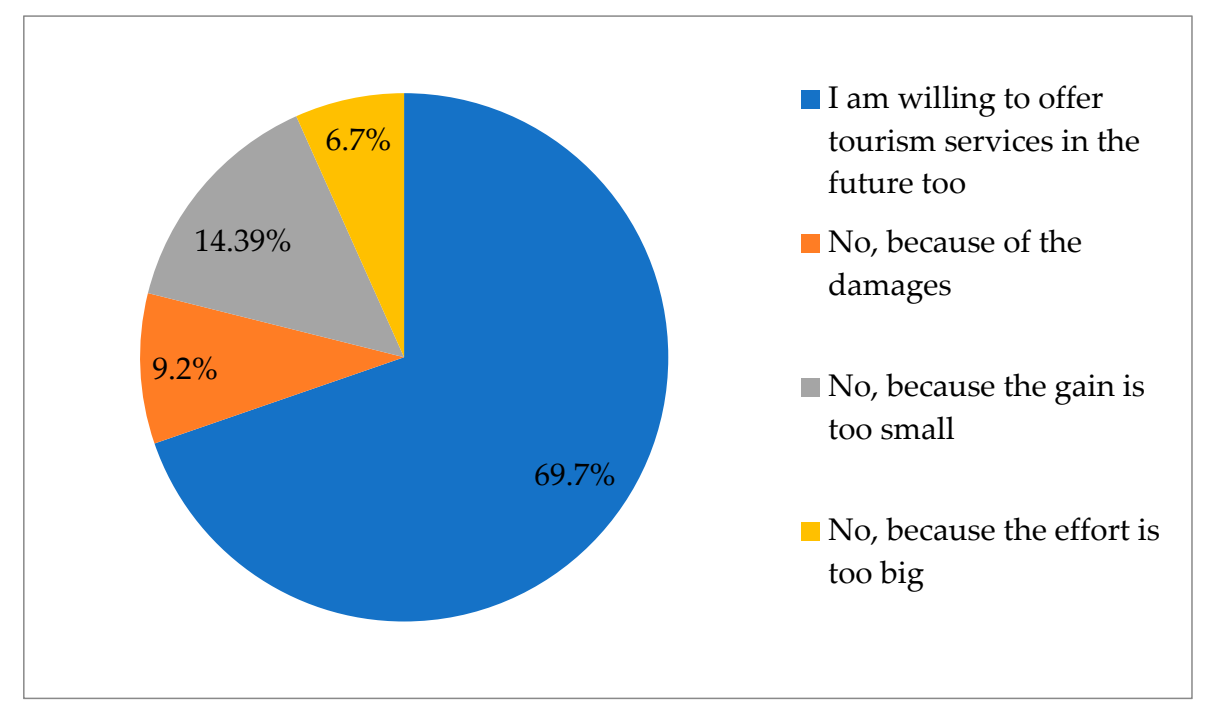

Figure 2. Local respondents' willingness to offer tourism services in the future.

\subsection{Analyzing the Festival's Socio-Cultural Benefits for the Community}

The festival's social benefits for the community were analyzed using two dimensions: community benefits (Mean $=3.84 \pm 0.913$ ) and cultural-educational benefits (Mean $=4.05 \pm 0.922$ ). It is obvious that, for the community of Bontida, the music festival brought more culturaleducational benefits than community benefits and the respondents agreed that "the festival acts as a showcase for new ideas" (Mean $=4.01 \pm 1.040$ ). However, the main benefit refers to the festival's capacity to offer to the community members a "variety of cultural experiences" (Mean $=4.14 \pm 1.012$ ). Besides that, the respondents have the occasion of "meeting festival performers/workers" (Mean $=4.11 \pm 1.093$ ) and the opportunity to learn new things (Mean $=3.95 \pm 1.118$ ) (Table 2). With regard to community benefits, the respondents were aware of the fact that the festival brings benefits to the perception of the community (Mean $=4.29 \pm 1.060$ ), which is now famous all over the country, as well as abroad, and that it helps the community to differentiate itself from others by having this unique and special competitive advantage (Mean $=4.01 \pm 1.119)$. Another positive impact is related to the possibility of sharing ideas within community groups, which is quite important for community members (Mean $=3.95 \pm 1.169$ ). The fact that the festival could contribute to the well-being of each community member was also appreciated as a positive impact (Mean $=3.52 \pm 1.229)$ (Table 2). The same positive attitude towards social benefits was observed among a community from Turkey [75].

Table 2. Means and standard deviations of the items referring to the festival's socio-cultural benefits.

\begin{tabular}{|c|c|c|}
\hline Items (1-Totally Disagree, 5-Totally Agree) & Mean & Std. Deviation \\
\hline Community benefits & 3.84 & 0.913 \\
\hline The festival enhances the image of the community & 4.29 & 1.060 \\
\hline The festival helps me to shows others why my community is unique and special & 4.01 & 1.119 \\
\hline The festival contributes to my personal well-being & 3.52 & 1.229 \\
\hline Assisting in organizing the festival helps to build leaders within my community & 3.43 & 1.245 \\
\hline The festival allows for the sharing of ideas among community groups & 3.95 & 1.169 \\
\hline Cultural/educational benefits & 4.05 & 0.922 \\
\hline Local respondents who participate in the festival have the opportunity to learn new things & 3.95 & 1.118 \\
\hline The festival acts as a showcase for new ideas & 4.01 & 1.040 \\
\hline I am exposed to a variety of cultural experiences through the community festival & 4.14 & 1.012 \\
\hline I enjoy meeting festival performers/workers & 4.11 & 1.093 \\
\hline
\end{tabular}




\subsection{Analyzing the Festival's Socio-Cultural Costs for the Community}

The festival's socio-cultural costs for the community were analyzed using two dimensions: "quality of life concerns" (Mean $=3.15 \pm 0.974$ ) and the "community resource concerns" (Mean = 2.84), and the reason for such an analysis consists of the strong link with the general perception on tourism development. Other research $[26,76,77]$ analyzed the negative impact that festival tourism could possibly have on the quality of life of community members. The respondents admit the fact that "car/bus/truck traffic increases during the festival", but the Mean value (3.63) with a standard deviation of 1.210 indicates the level is not too high to be perceived as unacceptable. Pedestrian traffic also increases but it is not very disturbing for the respondents (Mean $=3.21 \mathrm{SD}= \pm 1.131$ ), while noise is quite acceptable (Mean $=3.04 \mathrm{SD}= \pm 1.287$ ). Vandalism does not increase during the festival (Mean $=2.72 \pm 1.245$ ), which is quite remarkable compared to other research, which mentions traffic congestion, pedestrian traffic, ecological damage and overcrowding as negative aspects $[78,79]$ (Table 3$)$.

Table 3. Means and standard deviations of the items referring to the festival's socio-cultural costs.

\begin{tabular}{|c|c|c|}
\hline Items (1-Totally Disagree, 5-Totally Agree) & Mean & Std. Deviation \\
\hline Quality of life concerns & 3.15 & 0.974 \\
\hline Vandalism in my community increases during the festival & 2.72 & 1.245 \\
\hline Car/bus/truck/RV traffic increases to unacceptable levels during the festival & 3.63 & 1.210 \\
\hline Pedestrian traffic increases to unacceptable levels during the festivals & 3.21 & 1.131 \\
\hline Noise levels are increased to an unacceptable point during the festival & 3.04 & 1.287 \\
\hline Community resource concerns & 2.84 & 0.953 \\
\hline The festival is a source of negative competition between my community and neighboring communities & 2.29 & 1.295 \\
\hline Some people and/or groups in the community receive more of the benefits of the festival than do others & 3.61 & 1.200 \\
\hline Power is not equally distributed among groups in my community & 3.04 & 1.222 \\
\hline The festival overtaxes available community financial resources & 2.42 & 1.280 \\
\hline
\end{tabular}

\subsection{Analyzing the Sense of Well-Being of the Community}

In the present research, the sense of well-being was analyzed using three dimensions (Mean $=3.16 \pm 1.059)$, and the results indicate that the festival clearly brought up some positive feelings among community members, the most important aspect being related to the fact that the respondents admitted that it "was rewarding" (Mean $=3.28 \pm 1.093$ ), but also it "enriched their lives" (Mean = $3.21 \pm 1.176$ ) (Table 4). Given the fact that, among the community from Bontida, the item "quality of life concerns" had a mean of 3.15, it can be concluded that the sense of well-being is not negatively impacted.

Table 4. Means and standard deviations of the items referring to subjective well-being of respondents.

\begin{tabular}{ccc}
\hline Items (1-Totally Disagree, 5-Totally Agree) & Mean & Std. Deviation \\
\hline Subjective well-being of respondents & 3.16 & 1.059 \\
\hline $\begin{array}{c}\text { All in all, I feel this festival has enriched my life. I'm really glad I went on this festival } \\
\text { On this festival, I accomplished my purpose of the experience. This experience has } \\
\text { enriched me in some ways }\end{array}$ & 3.21 & 1.176 \\
$\begin{array}{c}\text { This festival was rewarding to me in many ways, I feel much better about things and } \\
\text { myself with this festival }\end{array}$ & 3.00 & 1.205 \\
\hline
\end{tabular}

Furthermore, the Shapiro-Wilk test was used to test the normality of the five categories of impact of festival tourism (community benefits, cultural/educational benefits, quality of life concerns, community concerns and subjective well-being of respondents) on the local community $(p<0.05)$; thus, the Mann-Whitney $U$ test was chosen to compare the two groups (female and male) and the Kruskal-Wallis test was used to analyzed whether there were any significant differences among the other groups based on age, educational level and monthly income (Table 5). The results revealed that males (Mean $=4.20$ ) perceived the 
impact of festival tourism regarding the cultural and educational benefits more positively than women $($ Mean $=3.91)(p<0.05)$, while women $($ Mean $=3.31)$ scored more for the quality of life concern than men (Mean $=2.98),(p<0.05)$. There is some research which emphasizes some gender differences regarding the perception of risk, with women being more preoccupied by environmental issues than men, even if they do not often agitate for environmental causes. Thus, the present results indicate the same tendency of women to prefer a safe life $[80,81]$.

Table 5. Importance of tourism impacts.

\begin{tabular}{|c|c|c|c|c|c|}
\hline Variables & Community Benefits & $\begin{array}{c}\text { Cultural/Educational } \\
\text { Benefits }\end{array}$ & $\begin{array}{l}\text { Quality of Life } \\
\text { Concerns }\end{array}$ & $\begin{array}{l}\text { Community } \\
\text { Resource Concerns }\end{array}$ & $\begin{array}{c}\text { Subjective } \\
\text { Well-Being of } \\
\text { Respondents }\end{array}$ \\
\hline \multicolumn{6}{|l|}{ Gender } \\
\hline Female & 3.75 & 3.91 & 3.31 & 2.83 & 3.09 \\
\hline Male & 3.92 & 4.20 & 2.98 & 2.85 & 3.24 \\
\hline$p$-value & 0.326 & $0.015^{*}$ & $0.038 *$ & 0.975 & 0.425 \\
\hline \multicolumn{6}{|l|}{ Age (years) } \\
\hline $18-29$ & 3.84 & 4.04 & 3.19 & 2.81 & 3.01 \\
\hline $30-39$ & 3.66 & 3.88 & 2.97 & 2.57 & 3.19 \\
\hline $40-49$ & 3.80 & 3.93 & 3.26 & 2.68 & 2.95 \\
\hline $50-59$ & 3.98 & 4.34 & 3.00 & 3.02 & 3.74 \\
\hline+60 & 4.00 & 4.18 & 3.39 & 3.45 & 3.19 \\
\hline $\begin{array}{c}\text { Kruskal-Wallis } \chi^{2} \\
\text { statistic, } p \text {-value }\end{array}$ & $\begin{array}{c}\chi^{2}=1.457 \\
\mathrm{df}=4, p=0.834\end{array}$ & $\begin{array}{c}\chi^{2}=2.247 \\
\mathrm{df}=4, p=0.690\end{array}$ & $\begin{array}{c}\chi^{2}=3.639 \\
\mathrm{df}=4, p=0.457\end{array}$ & $\begin{array}{c}\chi^{2}=7.787 \\
\mathrm{df}=4, p=0.100\end{array}$ & $\begin{array}{c}\chi^{2}=5.111 \\
\mathrm{df}=4, p=0.276\end{array}$ \\
\hline \multicolumn{6}{|l|}{ Educational level } \\
\hline Primary school & 3.76 & 3.79 & 3.17 & 2.91 & 3.25 \\
\hline High school & 3.72 & 4.00 & 3.20 & 2.98 & 3.13 \\
\hline Faculty & 3.91 & 4.12 & 3.03 & 2.71 & 3.00 \\
\hline Post-graduate & 4.40 & 4.75 & 3.30 & 2.32 & 3.86 \\
\hline $\begin{array}{c}\text { Kruskal-Wallis } \chi^{2} \\
\text { statistic, } p \text {-value }\end{array}$ & $\begin{array}{c}\chi^{2}=5.622 \mathrm{df}=3 \\
p=0.132\end{array}$ & $\begin{array}{c}\chi^{2}=3.835 \mathrm{df}=3 \\
p=0.280\end{array}$ & $\begin{array}{c}\chi^{2}=1.566 \mathrm{df}=3 \\
p=0.667\end{array}$ & $\begin{array}{c}\chi^{2}=5.456 \mathrm{df}=3 \\
p=0.141\end{array}$ & $\begin{array}{c}\chi^{2}=5.620 \mathrm{df}=3, \\
p=0.132\end{array}$ \\
\hline \multicolumn{6}{|l|}{$\begin{array}{l}\text { Monthly income per } \\
\text { person }\end{array}$} \\
\hline$<200$ euro & 3.91 & 4.00 & 3.44 & 2.96 & 2.88 \\
\hline 200-320 euro & 3.35 & 3.48 & 3.32 & 3.13 & 2.92 \\
\hline $321-440$ euro & 3.96 & 4.22 & 3.35 & 3.04 & 3.32 \\
\hline 441-560 euro & 4.15 & 4.55 & 2.81 & 2.50 & 3.47 \\
\hline 561-680 euro & 3.81 & 4.09 & 3.13 & 2.88 & 3.60 \\
\hline$>680$ euro & 3.82 & 3.96 & 2.95 & 2.59 & 2.93 \\
\hline $\begin{array}{c}\text { Kruskal-Wallis } \chi^{2} \\
\text { statistic, } p \text {-value }\end{array}$ & $\begin{array}{c}\chi^{2}=8.421 \mathrm{df}=5 \\
p=0.135\end{array}$ & $\begin{array}{c}\chi^{2}=20.314 \mathrm{df}=5 \\
p=0.001\end{array}$ & $\begin{array}{c}x^{2}=6.698 \mathrm{df}=5 \\
p=0.244\end{array}$ & $\begin{array}{c}x^{2}=9.074 \mathrm{df}=5 \\
p=0.106\end{array}$ & $\begin{array}{c}\chi^{2}=6.546 \mathrm{df}=5, \\
p=0.257\end{array}$ \\
\hline
\end{tabular}

In analyzing the age of the respondents, it can be concluded that those aged between 50 and 59 years perceived the "cultural/educational benefits" that the festival brought to their community more favorably (Mean $=4.34$ ), but each category of age scored high values for this item. The seniors are very pleased about the "community benefits" offered by the festival, scoring the highest value (Mean = 4.00), a fact which is important since they have observed the community's evolution for the longest period of time, meaning that the festival has brought a notable positive change within the community.

The "cultural/educational benefits" of the festival are perceived as the most important aspects for the community, regardless of education level or income, except for the category of individuals in primary school (Mean = 3.79). Moreover, for the "community benefits" item, only post-graduate respondents perceived it as having an important positive influence (Table 5).

\section{Discussions}

Therefore, how much does such an event affect its host community? The results of the study indicated that the respondents from Bontida commune are directly involved in offering different tourism services to the participants of the annual festival. Previous findings suggest that the support for tourism activities is linked to the personal benefits 
of the community members; thus, the higher the percentage of respondents involved in tourism activities, the stronger the support for tourism [3,54]. Similar findings were observed after conducting a study in the North-Western region of Romania, where the respondents perceive tourism development positively as being a source of income [6]. Another study conducted in a small rural community where tourism is at an emerging stage, just like the Bontida commune, noted the same positive support for tourism activities, as long as the personal benefits are notable [58].

It was observed that the support from the locals for tourism increases if the perceived benefits are more important than the perceived costs. The cultural/educational benefits are perceived as being the most important by the respondents compared to the perceived costs; therefore, it can be concluded that their support for tourism is strong and that the premises for building a destination brand are fulfilled. This stage could be possible with the aid of all stakeholders involved who interested in developing a sustainable tourism product (government, local authorities and private operators).

Can a music festival improve socio-cultural development and the wellbeing of rural residents? The rapid growth of the segment of festivals and events has led to the need to measure the impact which they could possibly have on a host community [79]; this is strictly related to overall acceptability. Generally, a positive effect was observed regarding the festival's impact on the socio-cultural life of respondents, but there are also exceptions, such as when social benefits are almost equal to social costs [82,83].

The sense of well-being was previous analyzed by Yolal et al. [26] with the aim of identifying the impact of festivals on community perception. Findings revealed that community and cultural benefits are positive predictors of a community's well-being, while the quality of life concerns had a negative impact. Art festivals are considered to lead to personal well-being, with a living legacy for the community [84], and facilitate participation by developing resilience among the community members. Festivals are considered to have the role of creating a community [85] and, for each community, it is necessary to analyze the well-being of the respondents using as outcomes such as "livability", "sustainability", "viability" and "vitality" [86,87]. The results from the present study indicated that the music festival clearly had a positive impact on the respondents' well-being, bringing positive feelings among the community and being rewarding.

Do socio-demographic characteristics affect the perception of cultural impacts? The socio-cultural impact is perceived differently by males and females. It has been observed that males are more preoccupied by socio-cultural benefits than women, who instead are focused on stability and risk avoidance $[80,81]$. Given the fact that, within the Romanian rural areas, women's participation in public life is not yet at the same level as men's, the key factors involved in developing future tourism strategies should rely more on the men's support. Regarding the respondents' age, socio-cultural impact is perceived differently depending on this socio-demographic variable; older respondents perceived the socio-cultural impact more positively, reinforcing previous studies [3,61-65].

The socio-cultural impact is also perceived differently depending on the level of studies of the respondents; the higher the education level is, the more favorable the perception is regarding the socio-cultural benefits of festival tourism. These findings confirm those found in previous research [65-69].

The study conducted among the respondents from the rural community of Bontida village had the main aim of identifying the community support for tourism development given the international music festival that takes place annually. The music festival represents a big opportunity for the rural community to become an important tourist destination, but also to gain numerous advantages given the need for local tourism services. Romanian tourism has enormous potential for offering tourism products based on rural tourism, nature and adventure, as well as cultural tourism and city-breaks [36]. Unfortunately tourism's contribution to gross domestic product still remains low compared to other countries from the European Union. Therefore, given the huge success of the music festival and the growing demand for tourism services within the Bontida community, it is mandatory 
to identify whether the respondents' support is strong enough to build a real tourism brand and develop a sustainable tourism strategy within the commune. Due to previous research [13-23] which indicates a strong relationship between tourism support and economic activity, one of the issues which must be clarified is whether the respondents were involved in offering tourism services to the tourists; the results reflect a strong involvement. As much research focuses on the economic benefits for the community, it was also necessary to consider the socio-cultural dimensions which impact the community either by benefits or costs, as well as the impact that the festival has on respondents' well-being.

For the Bontida respondents, the festival brought up more socio-cultural benefits than costs, a fact that illustrates the importance of such events for the cultural life of the community. Socio-cultural costs are not relevant for the respondents, so the premises to develop sustainable tourism within the community would have the support of the local community, and the benefits are higher than the perceived costs.

The managerial implications of the study can be explained by the fact that Bontida commune is very new on the tourism map of destinations, and the potential for developing a sustainable tourism is high, as is the possibility for building a tourism brand which could attract other events in the future. The study also has also some limitations related to the representativeness of the research sample in the original population. At the same time, the research represents a first step for analyzing the impact of a music festivals on rural communities in Romania, as previous studies focused more on the perceptions of tourists participating in these festivals $[88,89]$.

Author Contributions: Conceptualization, D.I.C. and I.C.M.; Data curation, D.I.C.; Formal analysis, I.C.M. and G.O.C.; Methodology, I.C.M.; Software, R.H.; Supervision, D.I.C.; Validation, D.I.C. and G.O.C.; Visualization, F.H.A.; Writing—original draft, D.I.C. and G.O.C.; Writing-review \& editing, D.I.C., R.H., I.C.M. and G.O.C. All authors have read and agreed to the published version of the manuscript.

Funding: This research received no external funding.

Institutional Review Board Statement: Ethical review and approval were waived for this study due to the fact that participation was voluntary and all data were anonymous.

Informed Consent Statement: Informed consent was obtained from all participants in the study.

Data Availability Statement: Not applicable.

Conflicts of Interest: The authors declare no conflict of interest.

\section{References}

1. Perdue, R.R.; Long, P.T.; Allen, L. Rural Resident Tourism Perceptions and Attitudes. Ann. Tour. Res. 1987, 14, 420-429. [CrossRef]

2. Perdue, R.R. Resident Support for Tourism Development. Ann. Tour. Res. 1990, 17, 586-599. [CrossRef]

3. Mcgehee, N.G.; Andereck, K.L. Factors Predicting Rural Residents' Support of Tourism. J. Travel Res. 2004, 43, 131-140. [CrossRef]

4. Nunkoo, R.; Ramkissoon, H. Residents' Satisfaction with Community Attributes and Support for Tourism. J. Hosp. Tour. Res. 2011, 35, 171. [CrossRef]

5. Nunkoo, R.; Gursoy, D. Residents' support for tourism: An Identity Perspective. Ann. Tour. Res. 2012, 39, 243-268. [CrossRef]

6. Muresan, I.; Oroian, C.; Harun, R.; Arion, F.H.; Porutiu, A.; Chiciudean, G.O.; Todea, A.; Lile, R. Local Residents' Attitude toward Sustainable Rural Tourism Development. Sustainability 2016, 8, 100. [CrossRef]

7. Rasoolimanesh, S.M.; Ringle, C.M.; Jaafar, M.; Ramayah, T. Urban vs. rural destinations: Residents' perceptions, community participation and support for tourism development. Tour. Manag. 2017, 60, 147-158. [CrossRef]

8. Kanwal, S.; Rasheed, M.I.; Pitafi, A.H.; Pitafi, A.; Ren, M. Road and transport infrastructure development and community support for tourism: The role of perceived benefits, and community satisfaction. Tour. Manag. 2020, 77, 104014. [CrossRef]

9. Huang, J.Z.; Li, M.; Cai, L.A. A model of community-based festival image. Int. J. Hosp. Manag. 2010, 29, 254-260. [CrossRef]

10. Dwyer, L.; Mellor, R.; Mistilis, N.; Mules, T. A framework for assessing 'tangible' and 'intangible' impacts of festivals and conventions. Event Manag. 2000, 6, 175-189. [CrossRef]

11. Faulkner, B.; Chalip, L.; Brown, G.; Jago, L.; March, R.; Woodside, A. Monitoring the tourism impacts of the Sydney 2000 Olympics. Event Manag. 2001, 6, 231-246. [CrossRef]

12. Frost, W.; Frost, J. Events and tourism. In The Routledge Handbook of Events; Routledge: London, UK, 2020 ; pp. 76-92. 
13. O'Sullivan, D.; Jackson, M.J. Festival Tourism: A Contributor to Sustainable Local Economic Development? J. Sustain. Tour. 2002, 10, 325-342. [CrossRef]

14. Litvin, S.W.; Fetter, E. Can a festival be too successful? A review of Spoleto, USA. Int. J. Contemp. Hosp. Manag. 2006, 18, 41-49. [CrossRef]

15. Okech, R.N. Promoting sustainable festival events tourism: A case study of Lamu Kenya. Worldw. Hosp. Tour. Themes 2011, 3, 193-202. [CrossRef]

16. Walpole, M.J.; Goodwin, H.J. Local Economic Impacts of Dragon Tourism in Indonesia. Ann. Tour. Res. 2000, 27, 559-576. [CrossRef]

17. Gursoy, D.; Kim, K.; Uysal, M. Perceived impacts of festivals and special events by organizers: An extension and validation. Tour Manag. 2004, 25, 171-181. [CrossRef]

18. Gursoy, D.; Rutherford, D.G. Host attitudes toward tourism: An Improved Structural Model. Ann. Tour. Res. 2004, 31, 495-516. [CrossRef]

19. Pizam, A. Tourism's Impacts: The Social Costs to the Destination Community as Perceived by Its Residents. J. Travel Res. 1978, 16, 8-12. [CrossRef]

20. Allen, L.R.; Long, P.T.; Perdue, R.R.; Kieselbach, S. The impact of tourism development on residents' perceptions of community life. J. Travel Res. 1988, 27, 16-21. [CrossRef]

21. Davis, D.; Allen, J.; Cosenza, R.M. Segmenting Local Residents by Their Attitudes, Interests, and Opinions toward Tourism. J. Travel Res. 1988, 28, 2-8. [CrossRef]

22. Long, P.T.; Perdue, R.R.; Allen, L. Rural Resident Tourism Perceptions and Attitudes by Community Level of Tourism. J. Travel Res. 1990, 28, 3-9. [CrossRef]

23. Jurowski, C.; Uysal, M.; Williams, R.D. A Theoretical Analysis of Host Community Resident Reactions to Tourism. J. Travel Res. 1997, 36, 3-11. [CrossRef]

24. Harun, R.; Chiciudean, G.; Sirwan, K.; Arion, F.; Muresan, I. Attitudes and Perceptions of the Local Community towards Sustainable Tourism Development in Kurdistan Regional Government, Iraq. Sustainability 2018, 10, 2991.

25. Dwyer, L.; Mellor, R.; Mistilis, N.; Mules, T. A framework for evaluating and forecasting the impacts of special events. Event Manag. 2000, 6, 191-204. [CrossRef]

26. Yolal, M.; Gursoy, D.; Uysal, M.; Kim, H.; Karacaoglu, S. Impacts of festivals and events on residents' well-being. Ann. Tour. Res. 2016, 61, 1-18. [CrossRef]

27. Allen, J.; Harris, R.; Jago, L.K.; Veal, A.J. Events beyond 2000: Setting the Agenda; Lindfield, N.S.W., Ed.; Australian Centre for Event Management: Sydney, Australia, 2000; pp. 31-45.

28. Mamirkulova, G.; Mi, J.; Abbas, J.; Mahmood, S.; Mubeen, R.; Ziapour, A. New Silk Road infrastructure opportunities in developing tourism environment for residents better quality of life. Glob. Ecol. Conserv. 2020, 24, e01194.

29. Stetic, S. Specific features of rural tourism destinations management. J. Settl. Spat. Plan. Spec. Issue 2012, 1, $131-137$.

30. Muresan, I.; Harun, R.; Arion, F.H.; Oroian, C.F.; Dumitras, D.E.; Mihai, V.C.; Ilea, M.; Chiciudean, D.I.; Gliga, I.D.; Chiciudean, G.O. Residents' Perception of Destination Quality: Key Factors for Sustainable Rural Development. Sustainability 2019, 11, 2594. [CrossRef]

31. Gibson, C.; Connell, J. (Eds.) Festival Places: Revitalising Rural Australia; Channel View Publications: Bristol, UK, 2011 ; p. 27.

32. Niñerola, A.; Sánchez-Rebull, M.-V.; Hernández-Lara, A.-B. Tourism Research on Sustainability: A Bibliometric Analysis. Sustainability 2019, 11, 1377. [CrossRef]

33. Available online: https://incomingromania.org/industry/solutii-organizare-sustinere-turismului-romanesc-alianta-pentruturism/ (accessed on 12 April 2021).

34. Matei, F.D. Cultural tourism potential, as part of rural tourism development in the North-East of Romania. Procedia Econ. Financ. 2015, 23, 453-460. [CrossRef]

35. Ban, F.; Hincu, D.; Ioan, I. Potential of rural tourism in Romania. J. Tour. 2010, 10, $28-31$.

36. The World Bank. National Tourism Development Strategy 2019-2030; The World Bank: Bucharest, Romania, 2018; Volume I.

37. Abbas, J.; Mubeen, R.; Terhemba Iorember, P.; Raza, S.; Mamirkulova, G. Exploring the impact of COVID-19 on tourism: Transformational potential and implications for a sustainable recovery of the travel and leisure industry. Curr. Res. Behav. Sci. 2021, 2, 100033. [CrossRef]

38. Skoultsos, S.; Tsartas, P. Event tourism: Statements and questions about its impacts on rural areas. Tourismos 2009, 4, 293-310.

39. Ohmann, S.; Jones, I.; Wilkes, K. The perceived social impacts of the 2006 Football World Cup on Munich residents. J. Sport Tour. 2006, 11, 129-152. [CrossRef]

40. Dwyer, L.; Forsyth, P.; Spurr, R. Estimating the impacts of special events on an economy. J. Travel Res. 2005, 43, 351-359. [CrossRef]

41. Besculides, A.; Lee, M.E.; McCormick, P.J. Resident's perceptions of the cultural benefits of tourism. Ann. Tour. Res. 2002, 29, 303-319. [CrossRef]

42. Duarte, P.; Folgado-Fernández, J.A.; Hernández-Mogollón, J.M. Measurement of The Impact of Music Festivals on Destination Image: The Case of a Womad Festival. Event Manag. 2018, 22, 517-526. [CrossRef]

43. Chang, P.J.; Wray, L.; Lin, Y. Social relationships, leisure activity, and health in older adults. Health Psychol. 2014, 33, 516-523. [CrossRef] 
44. Newman, D.B.; Tay, L.; Diener, E. Leisure and Subjective Well-Being: A Model of Psychological Mechanisms as Mediating Factors. J. Happiness Stud. 2014, 15, 555-578. [CrossRef]

45. Packer, J.; Ballantyne, J. The impact of music festival attendance on young people's psychological and social well-being. Psychol. Music 2011, 39, 164-181. [CrossRef]

46. Jaeger, K.; Mykletun, R.J. Festivals, Identities, and Belonging. Event Manag. 2013, 17, 213-226. [CrossRef]

47. Derrett, R. Festivals \& Regional Destinations: How Festivals Demonstrate a Sense of Community \& Place. Rural Soc. 2003, 13, 1. [CrossRef]

48. Hrivnák, M.; Moritz, P.; Melichová, K.; Roháčiková, O.; Pospišová, L. Designing the Participation on Local Development Planning: From Literature Review to Adaptive Framework for Practice. Societies 2021, 11, 19. [CrossRef]

49. Brida, J.G.; Disegna, M.; Osti, L. Residents' perceptions of tourism impacts and attitudes towards tourism policies in a small mountain community. In Proceedings of the Ninth Canadian Congress on Leisure Research, Wolfville, NS, Canada, $12-15$ May 1999.

50. Ko, D.W.; Stewart, W.P. A structural equation model of residents' attitudes for tourism development. Tour. Manag. 2002, 23, 521-530. [CrossRef]

51. Eraqi, M.I. Local communities' attitudes towards impacts of tourism development in Egypt. Tour. Anal. 2007, 12, 191-200.

52. Huong, P.M.; Lee, J.H. Finding important factors affecting local residents' support for tourism development in Ba Be National Park, Vietnam. For. Sci. Technol. 2017, 13, 126-132. [CrossRef]

53. Mohammadi, M.; Khalifah, Z.; Hosseini, H. Local people perceptions toward social, economic and environmental impacts of tourism in Kermanshah (Iran). Asian Soc. Sci. 2010, 6, 220-225. [CrossRef]

54. Ramseook-Munhurrun, P.; Naidoo, P. Residents' attitudes toward perceived tourism benefits. Int. J. Manag. Mark. Res. 2011, 4, 45-56.

55. Min, Z.; Xiaoli, P.; Bihu, W. Research on residents' perceptions on tourism impacts and attitudes: A case study of Pingyao ancient city. In Proceedings of the 6th Conference of the International Forum on Urbanism (IFoU), Tourbanism, Barcelona, Spain, 25-27 January 2012; pp. 1-10.

56. Aman, J.; Abbas, J.; Mahmood, S.; Nurunnabi, M.; Bano, S. The Influence of Islamic Religiosity on the Perceived Socio-Cultural Impact of Sustainable Tourism Development in Pakistan: A Structural Equation Modeling Approach. Sustainability 2019, 11, 3039. [CrossRef]

57. Garrigos-Simon, F.J.; Narangajavana-Kaosiri, Y.; Lengua-Lengua, I. Tourism and Sustainability: A Bibliometric and Visualization Analysis. Sustainability 2018, 10, 1976. [CrossRef]

58. Wang, Y.; Pfister, R.E. Residents' Attitudes Toward Tourism and Perceived Personal Benefits in a Rural Community. J. Travel Res. 2008, 47, 84-93. [CrossRef]

59. Sinclair-Maragh, G. Demographic analysis of residents' support for tourism development in Jamaica. J. Destin. Mark. Manag. 2017, 6, 5-12. [CrossRef]

60. Masonh, P.; Cheyne, J. Residents attitudes to proposed tourism development. Ann. Tour. Res. 2000, $27,391-411$.

61. Harrill, R. Residents' attitudes toward tourism development: A literature review with implications for tourism planning. J. Plan. Lit. 2004, 18, 251-266.

62. Tichaawa, T.M.; Makoni, L. Sociodemographic Influences on Residents' Perceptions of Tourism Development in Zimbabwe. GeoJ. Tour. Geosites 2018, 22, 432-446.

63. Deng, J.; Arbogast, D.; Selin, S. Community-based tourism planning: An application of the APPA approach to Anstead, West Virginia. Tour. Anal. 2011, 16, 601-615.

64. Tomljenovic, R.; Faulkner, B. Tourism and older residents in a Sunbelt Resort. Ann. Tour. Res. 2000, $27,93-114$.

65. Haralambopoulos, N.; Pizam, A. Perceived impacts of tourism: The case of Samos. Ann. Tour. Res. 1996, 23, 503-526.

66. Korça, P. Resident perceptions of tourism in a resort town. Leis. Sci. 1998, 20, 193-212.

67. Smith, M.D.; Krannich, R.S. Tourism dependence and resident attitudes. Ann. Tour. Res. 1998, $25,783-802$.

68. Hernández, S.; Cohen, J.; García, H. Residents' attitudes towards an instant resort enclave. Ann. Tour. Res. 1996, 23, 755-779.

69. Teye, V.; Sönmez, S.F.; Sirakaya, E. Residents' attitudes toward tourism development. Ann. Tour. Res. 2002, 29, 668-688.

70. Long, P.H.; Kayat, K. Residents' perceptions of tourism impact and their support for tourism development: The case study of Cuc Phuong National Park, Ninh Binh province, Vietnam. Eur. J. Tour. Res. 2011, 4, 123-146.

71. Available online: http:/ / comunabontida.ro/prezentare/ (accessed on 28 March 2020).

72. Available online: http://statistici.insse.ro:8077/tempo-online/\#/pages/tables/insse-table (accessed on 28 March 2020).

73. Saleh, A.; Bista, K. Examining Factors Impacting Online Survey Response Rates in Educational Research: Perceptions of Graduate Students. J. Multidiscip. Eval. 2017, 13, 63-74.

74. Hair, J.F.; Anderson, R.E.; Tatham, R.L.; Black, W.C. Multivariate Data Analysis, 5th ed.; Prentice Hall: Upper Saddle River, NJ, USA, 1998.

75. Bagiran, D.; Kurgun, H. A research on social impacts of the Foça Rock Festival: The validity of the Festival Social Impact Attitude Scale. Curr. Issues Tour. 2016, 19, 63-90. [CrossRef]

76. Pavluković, V.; Armenski, T.; Alcántara-Pilar, J.M. Social impacts of music festivals: Does culture impact locals' attitude toward events in Serbia and Hungary? Tour. Manag. 2017, 63, 42-53. [CrossRef]

77. Düşmezkalender, E.; Özdemir, C.; Yolal, M. A Study on Perceived Socio-Economic Impacts of Cultural Festival on Local Residents Participation: Kafkasör Culture Tourism and Art Festival. Tur. Akad. Derg. 2019, 6, 121-130. 
78. Agbabiaka, H.I. Physical planning implication of Eyo festival in Lagos Island, Nigeria. Cogent Soc. Sci. 2016, 2, 1257461. [CrossRef]

79. Hancock, T.; Labonte, R.; Edwards, R. Indicators that count! Measuring population health at the community level. Can. J. Public Health 1999, 90 (Suppl. 1), S22-S26. [CrossRef]

80. Mohai, P. Men, women, and the environment: An examination of the gender gap in environmental concern and activism. Soc. Nat. Resour. Int. J. 1992, 5, 1-19. [CrossRef]

81. Barke, R.P.; Jenkins-Smith, H.; Slovic, P. Risk Perceptions of Men and Women Scientists. Soc. Sci. Q. 1997, 78, 167-176.

82. Wills, J. Just, Vibrant and Sustainable Communities, a Framework for Progressing and Measuring Community Wellbeing; Local Government Community Services of Australia: Townsville, Australia, 2001.

83. Small, K.; Edwards, D.; Sheridan, L. A Flexible Framework for Evaluating the Socio-Cultural Impacts of a (Small) Festivalinternational. J. Event Manag. Res. 2005, 1, 66-77.

84. Scholtz, M.; Viviers, P.A.; Maputose, L. Understanding the residents social impact perceptions of an african cultural festival and the African culture: The case of mACUFE. J. Tour. Cult. Chang. 2019, 17, 166-185. [CrossRef]

85. Derrett, R. Making Sense of How Festivals Demonstrate A Community's Sense of Place. Event Manag. 2002, 8, 49-58. [CrossRef]

86. Doe, F.; Preko, A.; Akroful, H.; Okai-Anderson, E.K. Festival tourism and socioeconomic development: Case of Kwahu traditional areas of Ghana. Int. Hosp. Rev. 2021. [CrossRef]

87. Brownett, T. Social capital and participation: The role of community arts festivals for generating wellbeing. J Appl. Arts Health 2018, 9, 71-84. [CrossRef]

88. Moisescu, O.; Gică, O.; Coros,, M.; Yallop, A. The UNTOLD story: Event tourism's negative impact on residents' community life and well-being. Worlds. Hosp. Tour. Themes 2019, 11, 492-505. [CrossRef]

89. Moisescu, O.I. Analiza Experienței Festivaliere si a Impactului Local al Festivalurilor Untold si Electric Castle în Anul 2017. Available online: http:/ / doi:10.13140/RG.2.2.25168.20480 (accessed on 23 May 2021). 